\title{
Organizational Culture and Spirituality Workplace: Empirical Study of Influence of Organizational Culture and Spirituality Workplace
}

\author{
Rolland Epafras Fanggidae \\ Doctor of Management Science at a concentration of Human Resources Management from the Universitas Padjadjaran Bandung - \\ Indonesia.
}

\begin{abstract}
In today's organizations, Human Resources is one of the important driving factor. By creating a humanistic work environment, employees are more creative and have a passion to do the job. In order to improve the quality and quantity of human resources needs to the strategy of the organization. One of the strategies that can be undertaken by the organization is the psychic and spiritual fulfillment of employees in order to create a work environment that is humane. Spirituality is not about the workplace as religious practices are organized and not on God or theology. In this study proposes a theory Spirituality workplace, through a review of the literature and empirical study shows the definition of spirituality, the effects on work attitudes, as well as clarify the link spirituality and culture of the organization. This research is done through empirical studies related link workplace spirituality and organizational culture on college lecturer in East Nusa Tenggara (NTT)-Indonesia. Data were collected through a survey with simple random sampling proportional and involve \pm 320 Lecturer Private college as respondents. Data analysis techniques with linear regression method using SPSS 23 determines the relationship between Organizational Culture and Spirituality workplace.
\end{abstract}

Keywords: Spirituality Workplace; Organizational Culture; Spirituality; Religion; Work Attitude.

\section{Introduction}

Today the role of human resources is increasingly important in terms of achieving organizational goals. Where, organizations require human resources who are willing to work hard, think creatively, and perform purple [1]. Human resources are a strategic factor in organizational activities, but problems often arise in the management of human factors. To be able to improve the quality of human resources need a strategy from the organization. Strategy in improving the quality of human resources is an effort to improve company performance and individual performance [2]. While the performance of individuals closely related to the work, while attitudes related to the ability of individual performance. This shows that, now there has been a shift in the organization view employees as human beings. Where human origin is valued as cost, has shifted where human is an asset that has many advantages.

This shift requires that the strategic management of human resources within the organization leads to a holistic approach, in which organizational management not only emphasizes economic gain or liability, but also has legal, ethical, and responsibility responsibilities to stakeholders (employees, customers, communities, and government). Thus organizational management is oriented towards employees, thus encouraging organizations to produce more humanistic work environments, increasing simplicity, more meaning, and relationships with something higher [3]. By creating a humanistic work environment, employees are more creative and have high morale in doing the work. Spirituality has a relationship with the work of behaviour in the form of job satisfaction, work performance, attitude, work ethic, morale and management [2]. So that one's spirituality will give awareness of the importance of social relations, work attitude and role in the organization.

The Spirituality Workplace approach becomes a strategy for organizations in the management of employees, where the spirituality workplace can be viewed from two levels, namely; individual level and organizational level [4]. Individual level, refers to the set of individual values that drive the transcendent experience through work processes, and facilitates feelings of connecting with others while providing a complete and happy feeling. Whereas, organizational level refers to the framework of organizational culture values that encourages the transcendent experience of employees through the process of working, facilitating feelings of connecting with others while providing a complete and happy feeling [4]. Thus, the spirituality workplace is an organization's recognition of human needs as a creature that has an inner dimension behind the physical element, it is that underlying humans as

\footnotetext{
*Corresponding author: fanggidae_jr@yahoo.co.id
} 
workers in organizations no longer work simply for money, but also make work as a journey to be able to grow and toward goals the greater one.

Various studies have confirmed spiritually at the individual level, but few studies of spirituality at the organizational level. So based on previous research, the research question in this papers; 'Can spirituality be implemented in the workplace for the creation of a humanist work environment, thus developing positive employee morale?'. Through theoretical studies of theory as well as empirical studies related to workplace spirituality links and organizational culture. The research was conducted on university lecturers in East Nusa Tenggara-Indonesia. Data were collected through survey with proportional and simple random sampling involving \pm 320 private college lecturers as respondents. While the data analysis using regression test with SPSS 23.00 to know the relationship between Organizational Culture and Spirituality workplace.

\section{Methodology}

The term Spirituality workplace appears to be an oxymoron: two ideas that appear at odds [5]. But in the context of the work environment, spirituality can be viewed from two levels according to Giacalone and Jurkiewicz [4] namely; "First, individual level", this level refers to the set of individual values that drive the transcendent experience through work processes, and facilitates feelings of connecting with others while providing a complete and happy feeling. "Second, organizational level", at this level refers to the framework of organizational cultural values that encourages the transcendent experience of employees through the process of working, facilitating feelings of connecting with others while providing a sense of complete and happy. When people experience spirituality in the workplace, they feel more attached to their organization and experience a sense of duty / loyalty in other words has a high organizational commitment [6].

For that at the organizational level, spirituality at work as the recognition that employees have an inner life that takes place in the context of community [7]. By Garcia-Zamor [8], the Spirituality workplace is defined as: "The recognition that people come to work has more of their bodies and minds; they bring unique individual talents and souls". Meanwhile, Gull \& Doh ${ }^{9}$ defines the Spirituality workplace as; "The assumption that when people find meaning in their activities they become more involved, more responsible, more ethical, more collaborative, and thus, more creative". In this concept Spirituality workplace is associated with activities that involve personal development, authenticity and purity, learning, involvement, truthseeking, meaning and managing for goals, affection, and higher community activities.

So from the various concepts, in this papers Spirituality workplace is "The recognition that employees have an inner life in an effort to find purpose in life, both in relationship with colleagues and have consistency or harmony between beliefs and values within the organization" [10]. In this papers the classification of the workplace's spirituality dimension consists of:

a) Meaningful work [11]. This is a fundamental aspect of Workplace Spirituality, which consists of the ability to feel the deepest meaning and purpose of one's work. This dimension represents how workers interact with their work day by day on an individual level. It is based on the assumption that humans have their own deepest motivation, truth and desire to carry out activities that bring meaning to their lives and the lives of others. After all, spirituality sees work not only as a fun and challenging thing, but also about things such as searching for deepest meaning and purpose, animating one's dreams, fulfilling one's life's needs by finding meaningful work, and contributing to others.

b) Calling [12]. A calling is the most satisfying form of work because, as a gratification, it is done for its own sake rather than for the material benefits it brings. Enjoying the resulting state of flow on the job will soon, I predict, overtake material reward as the principal reason for working. Corporations that promote this state for their employees will overtake corporations that rely only on monetary reward. Even more significantly, with life and liberty now covered minimally well, we are about to witness a politics that goes beyond the safety net and takes the pursuit of happiness very seriously indeed.

c) Sense of community [11]. This dimension refers to the group level of human behavior and focuses on the interaction between workers and co-workers. At this level spirituality consists of the mental, emotional, and spiritual relationships of workers in a team or group in an organization. The core of this community is the deep connection between people, including support, freedom of expression, and shelter.

d) Alignment with organizational values [11]. This third aspect shows the experiences of individuals who have strong alignments between their personal values and the mission and goals of the organization. This relates to the premise that the organization's purpose is greater than itself and one must contribute to the community or other parties.

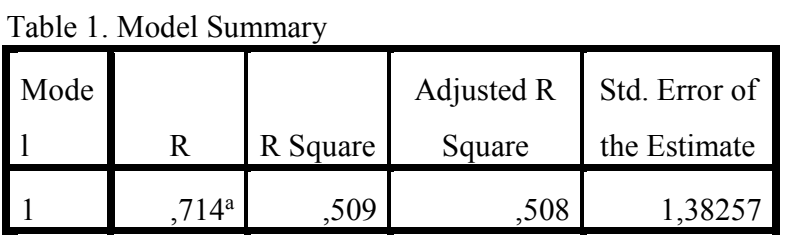

a. Predictors: (Constant), SW

Based on Summary Model Table, it shows the correlation value of $\mathrm{R}(0,714)$ and the coefficient of determination ( $\mathrm{R}$ Square $=0,509)$ which means that $50,9 \%$ Spirituality Workplace $(\mathrm{SW})$ variable can be 
explained by Organizational Culture (OC) variable, Table 2. Coefficients ${ }^{\mathbf{a}}$

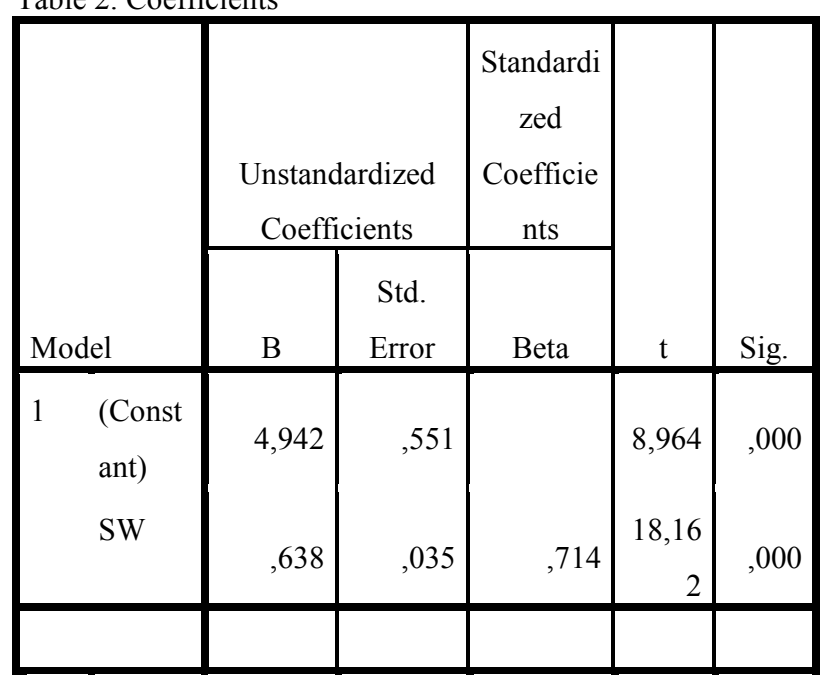

a. Dependent Variable: OC

while the rest $49,1 \%$ other variables.

From the Table of Coefficients showing the constant value of 4,942, the Spirituality Workplace (SW) regression coefficient of 0,638 , with t count of 18.162 and the significance $\mathrm{p}$ of $0.000<0.05$, then this means Organizational Culture has a significant effect on Spirituality Workplace.

\section{Discussion}

The result of the research shows that Organizational Culture has significant effect to Spirituality Workplace. An organization's culture is therefore an informal, shared way of perceiving life and membership in the organization that Wagner \& Hollenbeck [13]. In the process of helping to create mutual understanding of organizational life, Wagner \& Hollenbeck [13] organizational culture fulfills four basic functions; First, provide members of the organization's identity. Second, facilitate mutual commitment. Third, promote organizational stability. Fourth, forming behavior by helping members understand their environment. With the fulfillment of these four basic functions, the organizational culture serves as a social glue that helps to strengthen, coordinated behavior in the workplace. Thus, organizational culture can improve performance and serve as a valuable source of competitive advantage.

So that organizational culture refers to a system of shared meanings by members that differentiate organizations from other organizations. This awareness can be a strategy for the organization through the fulfillment of psychological and spiritual needs, thus creating a conducive working environment. Speaking of Spirituality workplace, the organizational culture is closely related, where the Spirituality workplace when viewed at the organizational level has relationship with organizational culture especially in the effort of creating a humane working environment. This is consistent with Giacalone and Jurkiewicz [4] research where Spirituality workplace at the organizational level refers to the framework of organizational culture values that encourages the transcendent experience of employees through the process of working, facilitating feelings of connecting with others while providing a complete and happy feeling. The same opinion is also confirmed in the Long \& Mills [14] study that members of the cultural approach organization have a role to understand the Spirituality workplace, thus affecting how people can understand the organizations in which they are members.

Sorakraikitikul, \& Siengthai [15], although in the context of Organizational learning culture, also shows a positive relationship between organizational learning culture and Spirituality workplace, where a friendly environment enables learning and performance improvement for organizational sustainability. Therefore the premise is obtained that is the relationship between organizational culture and Spirituality workplace.

Friendly environment such as good quality of society, healthy environment, and prosperous people lead to a good spiritual environment. Spiritual environment lead to religious people. It requires strong support from the environment such as peaceful environment.

\section{Conclusion}

Based on literature and empirical studies related to spirituality at the organizational level, the main conclusions are obtained as follows:

1. Spirituality workplace can be viewed from two levels, namely; level individual, refers to the set of individual values that drive the transcendent experience through work processes, and facilitates feelings of connecting with others while providing a complete and happy feeling. The organizational level refers to a framework of organizational cultural values that encourages the transcendent experience of employees through the process of working, facilitating feelings of connecting with others while providing a complete and happy feeling.

2. Historically, spirituality comes from religion, but the Spirituality workplace is not related to any religion. Spirituality in the workplace reflects employees' experiences such as sense of meaning, purpose, community, and transcendence in the workplace.

3. Based on Summary Model Table, shows the correlation value $\mathrm{R}(0,714)$ and coefficient of determination ( $\mathrm{R}$ Square $=0,509$ ) which means that $50,9 \%$ Spirituality Workplace variable can be explained by Organizational Culture variable, while the rest $49,1 \%$ explained by other variables.

4. From Table Coefficients shows a constant value of 4.942, Spirituality Workplace regression coefficient of 0,638 , with $t$ count of 18.162 and significance $\mathrm{p}$ of $0.000<0.05$, then this means Organizational Culture significant effect on Spirituality Workplace. 
5. Spirituality workplace when viewed at the organizational level has a relationship with organizational culture. Where for members of the cultural approach organizations play a role in understanding the Spirituality workplace, thus affecting how people can understand the organizations in which they are members. Thus, the premise is obtained that is the relationship between organizational culture and Spirituality workplace.

\section{References}

1. J. M. Ivancevich, R. Konopaske, M. T. Matteson, Perilaku dan Manajemen Organisasi, Edisi Ketujuh (Jilid 1), Penerbit Erlangga, Jakarta (2011).

2. A. Choerudin, The Relationship Between Spirituality and Work Attitude: A Empirical Study, Int. J. M. R. April 2014/ Volume 4/Issue 4/Article No-3/455-463, ISSN: 2249-7196 (2014).

3. J. F. Marques, The spiritual worker: An examination of the ripple effect that enhances quality of life in- and outside the work environment", J. M. D. 25.9 (2006): 884-895 (2006).

4. R. A. Giacalone \& C. L. Jurkiewicz, Handbook of workplace spirituality and organizational performance by M. E. Sharpe, Inc, ISBN 0-76560844-8. (2003).

5. G. F. A. Pierce, Spirituality@work:10 ways to balance your life on-the-job, Kanisius, Yogyakarta (2006).

6. R. E. Fanggidae, The Influence of Spirituality Workplace to Motivation, Job Satisfaction and
Organizational Commitment, Global J. Bus. Soc. Sci. Review 5 (3) 170 - 176 (2017).

7. D. P. Ashmos, \& D. Duchon, Spirituality at work: A conceptualization and measure, J. M. I., 9,134$146(2000)$.

8. J. C. Garcia Zamor, Workplace spirituality and organizational performance, Public Administration Review, May/Jun 2003, 63, 3, ProQuest. pg. 355 (2003).

9. G. Gull, J. A. \& J. Doh, The "Transmutation" of the Organization: Toward a More Spiritual Workplace, J. M. I, 13(2), 128-139 (2004).

10. R. E. Fanggidae, Y. Suryana, N. Efendi, Hilmiana, Effect of a Spirituality Workplace on Organizational Commitment and Job Satisfaction, Procedia - Social and Behavioral Sciences, 219 pp.639- 646 (2016).

11. J. Milliman, A. J. Czaplewski, and J. Ferguson, Workplace spirituality and employee work attitudes, An exploratory empirical assessment, J. O. C. M., 16 (4), 426-447 (2003).

12. M. E. P. Seligman, Authentic Happiness, ISBN 186471302X, 9781864713022, Publisher Random House, Australia (2011).

13. J. A. Wagner; J. R. Hollenbeck, Organizational behavior: securing competitive advantage, 5 th ed. 2005, Routledge Taylor \& Francis Group, an informa business (2010).

14. B. S. Long; J. Helms Mills, Workplace spirituality, contested meaning, and the culture of organization, A critical sensemaking account, J. O. C. M., Vol. 23 No. 3, pp. 325-341 (2010).

15. M. Sorakraikitikul, S. Siengthai, Organizational learning culture and workplace spirituality: Is knowledge-sharing behaviour a missing link?, The Environtment Organization, Vol. 21 Iss: 3, pp. 175 - 192. (2014). 